\title{
Reference gene selection for quantitative real-time PCR analysis in virus infected cells: SARS corona virus, Yellow fever virus, Human Herpesvirus-6, Camelpox virus and Cytomegalovirus infections
}

\author{
Aleksandar Radonić*1, Stefanie Thulke1, Hi-Gung Bae², Marcel A Müller², \\ Wolfgang Siegert ${ }^{1}$ and Andreas Nitsche ${ }^{2}$
}

Address: ${ }^{1}$ Charité - CCM, Medizinische Klinik II m.S. Hämatologie/Onkologie, Berlin, Germany and ${ }^{2}$ Robert Koch Institut, ZBS 1, Berlin, Germany Email: Aleksandar Radonić* - aleksandar.radonic@charite.de; Stefanie Thulke - stefanie.thulke@charite.de; Hi-Gung Bae - baeh@rki.de; Marcel A Müller - muellerm@rki.de; Wolfgang Siegert - wolfgang.siegert@charite.de; Andreas Nitsche - nitschea@rki.de

* Corresponding author

Published: 10 February 2005

Virology Journal 2005, 2:7 doi:10.1186/1743-422X-2-7

This article is available from: http://www.virologyj.com/content/2/I/7

(C) 2005 Radonić et al; licensee BioMed Central Ltd.

This is an Open Access article distributed under the terms of the Creative Commons Attribution License (http://creativecommons.org/licenses/by/2.0), which permits unrestricted use, distribution, and reproduction in any medium, provided the original work is properly cited.
Received: 03 February 2005

Accepted: 10 February 2005

\begin{abstract}
Ten potential reference genes were compared for their use in experiments investigating cellular mRNA expression of virus infected cells. Human cell lines were infected with Cytomegalovirus, Human Herpesvirus-6, Camelpox virus, SARS coronavirus or Yellow fever virus. The expression levels of these genes and the viral replication were determined by real-time PCR. Genes were ranked by the BestKeeper tool, the GeNorm tool and by criteria we reported previously. Ranking lists of the genes tested were tool dependent. However, over all, $\beta$-actin is an unsuitable as reference gene, whereas TATA-Box binding protein and peptidyl-prolyl-isomerase A are stable reference genes for expression studies in virus infected cells.
\end{abstract}

\section{Background}

Quantitative real-time PCR (QPCR) has become the favoured tool in mRNA expression analysis and also in virus diagnostics [1]. Real-time PCR has outperformed classical and semi-quantitative PCR methods in terms of accuracy, reproducibility, safety and convenience for the precise monitoring of viral load in clinical material, as well as for the investigation of the expression of cellular genes in response to virus infection. However, the most prominent problem in quantitative mRNA expression analysis is the selection of an appropriate control gene. For years, the glyceraldehyde 3-phosphate dehydrogenase (GAP) gene and the $\beta$-actin (Act) gene were used as control genes in classical molecular methods for RNA detection. Recently, evidence accumulated that especially these two genes, GAP and Act, are unsuitable controls in quantitative mRNA expression analysis due to setting depend- ent variations in expression [2-4]. Recently, we have confirmed these results by investigating the expressional stability of 13 potential reference genes in 16 different tissues and presented more suitable genes like the RNA polymerase II gene [5]. However, an evaluation of reference genes in virus infected cells has not been performed so far. Therefore, the selection of the 10 most promising reference genes, GAP, Act, peptidyl prolyl isomerase A (PPI), glucose 6-phosphate dehydrogenase (G6P), TATABox binding protein (TBP), $\beta 2$-microglobulin $(\beta 2 \mathrm{M}), \alpha-$ tubulin (Tub), ribosomal protein L13 (L13), phospholipase A2 (PLA) and RNA polymerase II (RPII) were evaluated in cell lines infected with members of different virus families: coronavirus (SARS-coronavirus), flavivirus (yellow fever virus, (YF)), herpesvirus (Human herpesvirus-6 (HHV-6) and cytomegalovirus (CMV)) and orthopoxvirus camelpox (CAMP), covering also DNA and RNA viruses. 
Table I: Cell culture conditions and results of virus kinetics

\begin{tabular}{|c|c|c|c|c|c|}
\hline & CMV & $\mathrm{HHV}-6$ & CAMP & SARS & YF \\
\hline cell line & MRC-5 & CCRF-HSB-2 & HepG2 & Huh-7DI2 & HepG2 \\
\hline multiplicity of infection & 2.0 & 0.5 & 0.5 & 1.0 & 0.5 \\
\hline time to maximal infection $/ \mathrm{h}$ & 72 & 120 & 24 & 72 & 96 \\
\hline max. infected cells \% & 100 & $>70$ & $>90$ & $>70$ & $>80$ \\
\hline measuring point $/ \mathrm{h}$ & $0,6,12,24,48,72$ & $0,24,48,72,96,120$ & $0,1,3,6,12,24$ & $0,2,4,22,42$ & $0,24,48,72,96$ \\
\hline
\end{tabular}

Table 2: Results from BestKeeper analysis, SD $\left[ \pm \mathrm{C}_{\mathrm{T}}\right]$

\begin{tabular}{cccccccccccccc}
\hline & RPII & Act & $\beta 2 M$ & LI3 & PLA & TBP & GAP & PPI & G6P & Tub & BK & sum $R G C$ \\
\hline CMV & 0.59 & 2.70 & 0.51 & 0.36 & 0.72 & 0.41 & 0.66 & 0.43 & 0.71 & 0.69 & 0.56 & 7.78 \\
HHV-6 & 2.77 & 1.09 & 0.50 & 0.87 & 0.88 & 0.35 & 0.59 & 0.26 & 0.92 & 0.78 & 0.63 & 9.02 \\
CAMP & 1.84 & 2.70 & 1.46 & 2.34 & 1.72 & 0.49 & 0.61 & 0.70 & 1.47 & 1.36 & 1.10 & 14.70 \\
SARS & 0.39 & 1.72 & 0.41 & 0.53 & 0.58 & 0.32 & 0.56 & 0.34 & 0.81 & 0.55 & 0.40 & 6.21 \\
YF & 1.36 & 3.06 & 1.07 & 0.67 & 1.64 & 0.71 & 1.08 & 0.56 & 0.80 & 1.19 & 0.98 & 12.16 \\
\hline sum $_{V}$ & 6.95 & 11.28 & 3.96 & 4.77 & 5.55 & 2.29 & 3.49 & 2.29 & 4.71 & 4.58 & \\
\hline
\end{tabular}

Quantification of viral RNA was performed to proof and monitor infection. Thereafter the candidate reference genes were evaluated by the BestKeeper tool [6], the GeNorm tool [7] and the algorithm we described previously [5].

\section{Results}

An efficient infection could be evidenced by a significant increase of viral RNA or DNA for all 5 viruses over time (table 1). Despite progressing viral replication, the expression of some of the reference genes remained constant, while other genes were varying in expression according to accumulation of infected cells.

The experimentally obtained data for each virus and each gene were analysed using three different methods. The reference gene evaluation of the BestKeeper tool is shown in table 2. A low standard deviation $(\mathrm{SD})$ of the $\mathrm{C}_{\mathrm{T}}$ values should be expected for useful reference genes and a high $\mathrm{SD}$ for genes that are susceptible to virus replication. Corresponding to the recent estimation the $\mathrm{SD}$ of the $\mathrm{C}_{\mathrm{T}}$ value was highest for Act in 4 of 5 viruses, indicating that Act is no reliable reference gene in this setting. In contrast, TBP and PPI displayed the highest expressional stability for 4 of 5 viruses. To find a general conclusion, the total of all $\mathrm{SD}$ values from all virus experiments $\left(\mathrm{sum}_{\mathrm{V}}\right)$ was calculated for each reference gene. As shown in table 2, TBP and PPI seemed to be the least regulated genes in this analysis $\left(\operatorname{sum}_{v}=2.29\right.$ for both $)$, followed by GAP $\left(\operatorname{sum}_{v}=3.49\right)$ and $\beta 2 \mathrm{M}\left(\operatorname{sum}_{\mathrm{v}}=3.96\right)$. All other genes showed moderate total SD values $\left(\operatorname{sum}_{\mathrm{v}}>4.58\right)$, except Act $\left(\operatorname{sum}_{\mathrm{v}}=11.28\right)$, confirming to be the most inappropriate reference gene. It is remarkable that the obtained BestKeeper index values are low, despite the inclusion of Act in the calculation. Calculating BestKeeper vs. each reference gene using Pearson correlation displayed very inconsistent results (table 3 ). Act showed the highest SD values in all virus infections, but a significantly high correlation. In contrast TBP displayed low correlation that was statistically not significant in most cases. When summing up the SD values of all reference genes for each virus infection ( sum $_{\mathrm{HRG}}$ ), it seems that CAMP infection caused the highest variations in reference gene expression.

Analysing the expression data with the GeNorm tool showed slightly deviant results (table 4). First, the value $\operatorname{sum}_{\mathrm{V}}$, representing the SD of a reference gene over all viruses, was lowest for PPI $\left(\operatorname{sum}_{V}=6.08\right)$ confirming the results obtained by the Bestkeeper tool. However, $\beta 2 \mathrm{M}$ $\left(\operatorname{sum}_{V}=6.11\right)$, GAP $\left(\operatorname{sum}_{V}=6.19\right)$ and TBP $\left(\operatorname{sum}_{V}=6.29\right)$ turned out to be comparably reliable as reference genes. Second, also the GeNorm tool showed that Act is by far the worst reference gene $\left(\operatorname{sum}_{\mathrm{V}}=14.20\right)$.

Applying the calculation mode presented previously [5], that is based on the calculation of $\Delta \Delta \mathrm{C}_{\mathrm{T}}$ values (table 5), Act was most susceptible to virus infection for 3 of 5 viruses and displayed the highest $\Delta \Delta \mathrm{C}_{\mathrm{T}}$ value over all viruses $\left(\operatorname{sum}_{V}=45.23\right)$. The two genes with the lowest $\Delta \Delta \mathrm{C}_{\mathrm{T}}$ value were TBP $\left(\operatorname{sum}_{\mathrm{V}}=9.82\right)$ and PPI $\left(\operatorname{sum}_{\mathrm{V}}=\right.$ 
Table 3: Results from BestKeeper analysis, Bestkeeper vs. Reference gene candidate

\begin{tabular}{|c|c|c|c|c|c|c|c|c|c|c|}
\hline $\begin{array}{l}\text { Coeff. of } \\
\text { corr. [r] } \\
\text { (p-Value) }\end{array}$ & RPII & Act & $\beta 2 M$ & LI3 & PLA & TBP & GAP & PPI & G6P & Tub \\
\hline CMV & $\begin{array}{c}0.75 \\
(0.005)\end{array}$ & $\begin{array}{c}0.79 \\
(0.002)\end{array}$ & $\begin{array}{c}0.76 \\
(0.005)\end{array}$ & $\begin{array}{c}0.13 \\
(0.698)\end{array}$ & $\begin{array}{c}0.89 \\
(0.001)\end{array}$ & $\begin{array}{c}0.10 \\
(0.763)\end{array}$ & $\begin{array}{c}0.92 \\
(0.001)\end{array}$ & $\begin{array}{c}0.91 \\
(0.001)\end{array}$ & $\begin{array}{c}0.75 \\
(0.005)\end{array}$ & $\begin{array}{c}0.95 \\
(0.001)\end{array}$ \\
\hline HHV-6 & $\begin{array}{c}0.79 \\
(0.002)\end{array}$ & $\begin{array}{c}0.73 \\
(0.007)\end{array}$ & $\begin{array}{c}0.54 \\
(0.069)\end{array}$ & $\begin{array}{c}0.30 \\
(0.350)\end{array}$ & $\begin{array}{c}0.93 \\
(0.001)\end{array}$ & $\begin{array}{c}0.79 \\
(0.002)\end{array}$ & $\begin{array}{c}0.94 \\
(0.001)\end{array}$ & $\begin{array}{c}0.75 \\
(0.005)\end{array}$ & $\begin{array}{c}0.82 \\
(0.001)\end{array}$ & $\begin{array}{c}0.97 \\
(0.001)\end{array}$ \\
\hline CAMP & $\begin{array}{c}0.91 \\
(0.002)\end{array}$ & $\begin{array}{c}0.18 \\
(0.662)\end{array}$ & $\begin{array}{c}0.98 \\
(0.001)\end{array}$ & $\begin{array}{c}0.95 \\
(0.001)\end{array}$ & $\begin{array}{c}0.99 \\
(0.001)\end{array}$ & $\begin{array}{c}0.78 \\
(0.022)\end{array}$ & $\begin{array}{c}0.63 \\
(0.092)\end{array}$ & $\begin{array}{c}0.99 \\
(0.001)\end{array}$ & $\begin{array}{c}0.45 \\
(0.268)\end{array}$ & $\begin{array}{c}0.59 \\
(0.127)\end{array}$ \\
\hline SARS & $\begin{array}{c}0.48 \\
(0.162)\end{array}$ & $\begin{array}{c}0.77 \\
(0.010)\end{array}$ & $\begin{array}{c}0.41 \\
(0.236)\end{array}$ & $\begin{array}{c}0.27 \\
(0.452)\end{array}$ & $\begin{array}{c}0.85 \\
(0.002)\end{array}$ & $\begin{array}{c}0.88 \\
(0.001)\end{array}$ & $\begin{array}{c}0.46 \\
(0.177)\end{array}$ & $\begin{array}{c}0.36 \\
(0.307)\end{array}$ & $\begin{array}{c}0.73 \\
(0.017)\end{array}$ & $\begin{array}{c}0.84 \\
(0.002)\end{array}$ \\
\hline YF & $\begin{array}{c}0.90 \\
(0.001)\end{array}$ & $\begin{array}{c}0.91 \\
(0.001)\end{array}$ & $\begin{array}{c}0.96 \\
(0.001)\end{array}$ & $\begin{array}{c}0.25 \\
(0.492)\end{array}$ & $\begin{array}{c}0.98 \\
(0.001)\end{array}$ & $\begin{array}{c}0.94 \\
(0.001)\end{array}$ & $\begin{array}{c}0.99 \\
(0.001)\end{array}$ & $\begin{array}{c}0.92 \\
(0.001)\end{array}$ & $\begin{array}{c}0.93 \\
(0.001)\end{array}$ & $\begin{array}{c}0.92 \\
(0.001)\end{array}$ \\
\hline
\end{tabular}

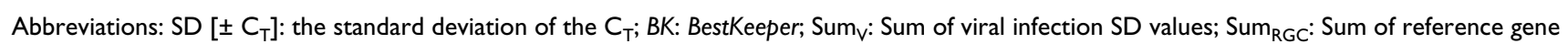
$S D$ values

Table 4: Results from GeNorm analysis $(M \leq 0.5)$

\begin{tabular}{ccccccccccccc}
\hline & RPII & Act & $\beta 2 M$ & LI3 & PLA & TBP & GAP & PPI & G6P & Tub & sum RGC \\
\hline CMV & 1.41 & 3.41 & 1.42 & 1.63 & 1.45 & 1.69 & 1.38 & 1.37 & 4.79 & 1.54 & 20.09 \\
HHV-6 & 2.82 & 1.38 & 1.15 & 1.55 & 1.19 & 1.03 & 0.95 & 1.08 & 1.15 & 0.96 & 13.27 \\
CAMP & 1.70 & 3.84 & 1.40 & 1.94 & 1.49 & 1.57 & 1.66 & 1.40 & 2.04 & 1.92 & 18.95 \\
SARS & 0.83 & 1.88 & 0.82 & 1.06 & 0.87 & 0.70 & 0.89 & 0.84 & 1.04 & 0.80 & 9.73 \\
YF & 1.65 & 3.69 & 1.32 & 1.87 & 2.02 & 1.30 & 1.31 & 1.39 & 1.31 & 1.48 & 17.34 \\
\hline sum $_{V}$ & 8.41 & 14.20 & 6.11 & 8.05 & 7.03 & 6.29 & 6.19 & 6.08 & 10.33 & 6.70 \\
\hline
\end{tabular}

Abbreviations: Sum $\mathrm{V}$ : Sum of viral infection GeNorm values; sum $_{\mathrm{RGC}}$ : sum of reference gene GeNorm values

Table 5: Results from $\Delta \Delta \mathbf{C}_{\mathrm{T}}$ analysis

\begin{tabular}{lccccccccccc}
\hline & RPII & Act & B2M & LI3 & PLA & TBP & GAP & PPI & G6P & Tub & sum \\
& & & & & & & & & \\
CMVC & 2.10 & 11.55 & 3.03 & 2.18 & 3.95 & 2.36 & 2.90 & 2.54 & 12.51 & 2.39 & 45.49 \\
HHV-6 & 5.98 & 3.54 & 3.35 & 2.89 & 4.99 & 0.88 & 2.27 & 1.25 & 3.35 & 2.30 & 30.78 \\
CAMP & 3.59 & 14.19 & 3.94 & 3.17 & 2.71 & 1.23 & 3.19 & 1.78 & 2.22 & 3.33 & 39.33 \\
SARS & 1.19 & 1.71 & 2.14 & 1.93 & 2.52 & 1.11 & 2.75 & 1.34 & 4.14 & 1.78 & 20.58 \\
YF & 9.01 & 14.25 & 5.78 & 2.90 & 9.62 & 4.24 & 6.35 & 3.14 & 5.42 & 7.48 & 68.17 \\
\hline sum $_{V}$ & 21.87 & 45.23 & 18.22 & 13.07 & 23.78 & 9.82 & 17.45 & 10.04 & 27.62 & 17.27 \\
\hline
\end{tabular}

Abbreviations: sum $\mathrm{V}_{\mathrm{V}}$ : sum of viral infection values; sum $_{\mathrm{RGC}}$ : sum of reference gene values

10.04), corresponding to the results of the Bestkeeper and the GeNorm tool.

\section{Discussion}

To date, it is generally accepted, that the selection of the ideal reference gene in gene expression analysis has to be done for each individual experimental setting by evaluat- ing several genes and using the best two or three of these genes as reference. Obviously there is no "one good gene for all experiments" recommendation. However, it is helpful to find putative candidates that can be shortlisted when setting up a new experimental design. Therefore, we determined the expression of previously tested reference genes in a setting of virus infected human cell lines. Capa- 
ble reference genes were evaluated using three independent methods: Bestkeeper, GeNorm and the $\Delta \Delta \mathrm{C}_{\mathrm{T}}$ method, and their results were compared.

All three tools ranked actin at the last position, indicating that it is an unsuitable reference gene in virus infected cells. The actin gene shows significant variations with increasing degree of infection.

The best genes obtained from all three calculation tools were TBP and PPI. TBP seems to be a relative stable expressed gene during the course of virus replication of different viruses in different cells. However, as previously shown [5] TBP is not expressed in all tissues and therefore its use may be limited.

Interestingly, classical reference genes like $\beta 2 \mathrm{M}$ and GAP were also acceptable regarding to a stable expression in virus infected cells. All other genes showed moderate expression stability.

The analysis of our data set according to the Bestkeeper tool revealed very good BestKeeper indices; even actin was included into our gene panel. These findings demonstrate the usefulness of analysing a wide variety of reference gene candidates. The inconsistent data regarding to the Bestkeeper calculation of the coefficient of correlation and the corresponding p-values may be a result of the Pearson correlation. As described by Pfaffl $e t$ al. its use is limited to groups without heterogeneous variances, but the tested reference genes have very different expression levels resulting in significant variances. Paffl et al. also described that new versions of Bestkeeper should circumvent these problems by use of Sperman and Kendall Tau correlation. However, one problem still remains to be solved; both tools, the BestKeeper and the GeNorm, can not compare paired probes. This is the great advantage of the $\Delta \Delta \mathrm{C}_{\mathrm{T}}$ method, or any other method which directly compares paired samples. From this point of view the use of a method like the $\Delta \Delta \mathrm{C}_{\mathrm{T}}$ should be applied first before considering additional tools for further elucidation of the acquired data.

\section{Conclusions}

In summary, TBP and PPI turned out to be the best reference genes in virus infected cells. These genes are a good point to start reference gene selection in gene expression studies in virus infection experiments.

\section{Material and Methods}

Virus culture and virus detection by real-time PCR

Camelpox strain CP-19, CMV strain AD169, HHV-6 strain U1102, SARS coronavirus strain 6109 and YFV strain 17D were propagated according to standard procedures [8-10].
The respective MOI and time of cell culture are shown in table 1 and were chosen to allow maximal infection as determined by immunofluorescence and real-time PCR [8-11]. For kinetic studies, cells were harvested at several time points (table 1) and RNA was extracted. The RNA transcription level of putative reference genes was determined by quantitative real-time PCR as described below.

\section{Extraction of RNA}

Total RNA from $1 \times 10^{6}$ cells was prepared using the QIAamp RNA Blood Mini Kit and RNase-free DNase set (Qiagen, Hilden, Germany) according to the manufacturer's recommendations for cultured cells. RNA solution was treated with DNA-free (Ambion, Huntingdon, United Kingdom).

\section{CDNA synthesis}

cDNA was produced using the Superscript III RT-PCR System (Invitrogen, Karlsruhe, Germany) according to the manufacturer's recommendations for oligo $(\mathrm{dT})_{20}$ primed cDNA-synthesis. cDNA synthesis was performed using 1 $\mu \mathrm{g}$ of RNA, at $50^{\circ} \mathrm{C}$. Finally, cDNA was diluted 1:5 before use in QPCR.

\section{Quantitative TaqMan PCR}

Primers, TaqMan probes and QPCR conditions for reference gene analysis were used as previously described [5]. PCR was performed in a Perkin Elmer 7700 Sequence Detection System in 96-well microtiter plates using a final volume of $25 \mu \mathrm{l}$.

\section{Calculations}

Analysis was performed with the BestKeeper [6] and GeNorm [7] tools. The $\Delta \Delta \mathrm{C}_{\mathrm{T}}$ value was calculated as follows: First the $\Delta \mathrm{C}_{\mathrm{T}}$ for each time point of probe assessment between virus and Mock infected cells was calculated. In a second step the maximal differences between the time points were calculated as $\Delta \Delta \mathrm{C}_{\mathrm{T}}$.

\section{Competing interests}

The author(s) declare that they have no competing interests.

\section{Authors' contributions}

AR conceived the study, carried out the HHV-6 experiments and real-time PCR assays and drafted the manuscript. ST carried out the CMV experiments. HB carried out the YF experiments. MM carried out the SARS experiments. WS participated in the design of the study. AN carried out the CAMP experiments, participated in design and coordination of the study and helped to draft the manuscript. All authors read and approved the final manuscript. 


\section{Acknowledgements}

We gratefully acknowledge the excellent technical assistance of Delia Barz and Jung-Won Sim-Bandenburg. The authors are grateful to Andreas Kurth for critical reading of the manuscript.

\section{References}

I. Mackay IM, Arden KE, Nitsche A: Real-time PCR in virology. Nucleic Acids Res 2002, 30: I292- 1305.

2. Glare EM, Divjak M, Bailey MJ, Walters EH: beta-Actin and GAPDH housekeeping gene expression in asthmatic airways is variable and not suitable for normalising mRNA levels. Thorax 2002, 57:765-770.

3. Selvey S, Thompson EW, Matthaei K, Lea RA, Irving MG, Griffiths LR: Beta-actin--an unsuitable internal control for RT-PCR. Mol Cell Probes 200I, 15:307-3II.

4. Zhong H, Simons JW: Direct comparison of GAPDH, betaactin, cyclophilin, and 28S rRNA as internal standards for quantifying RNA levels under hypoxia. Biochem Biophys Res Commun 1999, 259:523-526.

5. Radonic A, Thulke S, Mackay IM, Landt O, Siegert W, Nitsche A: Guideline to reference gene selection for quantitative realtime PCR. Biochem Biophys Res Commun 2004, 3 I 3:856-862.

6. Pfaffl MW, Tichopad A, Prgomet C, Neuvians TP: Determination of stable housekeeping genes, differentially regulated target genes and sample integrity: BestKeeper--Excel-based tool using pair-wise correlations. Biotechnol Lett 2004, 26:509-5I5.

7. Vandesompele J, De Preter K, Pattyn F, Poppe B, Van Roy N, De Paepe A, Speleman F: Accurate normalization of real-time quantitative RT-PCR data by geometric averaging of multiple internal control genes. Genome Biol 2002, 3:RESEARCH0034.

8. Bae HG, Nitsche A, Teichmann A, Biel SS, Niedrig M: Detection of yellow fever virus: a comparison of quantitative real-time PCR and plaque assay. J Virol Methods 2003, I I 0: |85-191.

9. Nitsche A, Muller CW, Radonic A, Landt O, Ellerbrok H, Pauli G, Siegert W: Human herpesvirus 6A DNA Is detected frequently in plasma but rarely in peripheral blood leukocytes of patients after bone marrow transplantation. J Infect Dis 2001, 183:130-133.

10. Hattermann K, Muller MA, Nitsche A, Wendt S, Donoso MO, Niedrig M: Susceptibility of different eukaryotic cell lines to SARScoronavirus. Arch Virol 2005 in press.

II. Nitsche A, Ellerbrok H, Pauli G: Detection of orthopoxvirus DNA by real-time PCR and identification of variola virus DNA by melting analysis. J Clin Microbiol 2004, 42: I207-I 2 I3.

\section{Publish with Bio Med Central and every scientist can read your work free of charge}

"BioMed Central will be the most significant development for disseminating the results of biomedical research in our lifetime. "

Sir Paul Nurse, Cancer Research UK

Your research papers will be:

- available free of charge to the entire biomedical community

- peer reviewed and published immediately upon acceptance

- cited in PubMed and archived on PubMed Central

- yours - you keep the copyright

Submit your manuscript here:

http://www.biomedcentral.com/info/publishing_adv.asp
BioMedcentral 